\title{
Phytochemical and pharmacological evaluation of methanolic extract of Lathyrus sativus L. seeds
}

\author{
Shovon Bhattacharjee ${ }^{1}$, Azhar Waqar', Kishan Barua ${ }^{1}$, Abhijit Das $^{2^{*}}$, Shukanta Bhowmik ${ }^{1}$ and Sumitra Rani Debi ${ }^{3}$
}

\begin{abstract}
Background: Lathyrus sativus L. (Fabaceae) has long been used as a traditional medicine for the treatment of several ailments such as Scabies, eczema, and allergy. The aim of the study was to evaluate the phytochemical nature with Central Nervous System (CNS) depressant, analgesic, antipyretic activities of the methanolic plant extract of Lathyrus sativus $L$. seeds in different experimental models.
\end{abstract}

Methods: Preliminary phytochemical screening and proximate analysis was carried out using different standard methods. CNS depressant activity was evaluated observing the effects of plant extract on Swiss albino mice using open field and hole-cross method. Acetic acid induced writhing and formalin induced paw licking methods were used for the appraisal of analgesic activity while 2,4-dinitrophenol (DNP) induced pyrexia model was used to investigate the antipyretic activity. The data were analyzed by one way ANOVA followed by Dunnett's test using SPSS (version 20).

Results: The phytochemical analysis revealed the presence of wide range of phytoconstituents in the plant extract. Our investigation demonstrated that the methanolic plant extract significantly $(p<0.001)$ decreased the locomotor activity of mice in open field and hole-cross method at both the tested doses (200 and $300 \mathrm{mg} / \mathrm{kg}$ ) which were comparable to the standard drug diazepam $(1 \mathrm{mg} / \mathrm{kg})$. The plant extracts significantly $(p<0.001)$ inhibited the writhing induced by acetic acid in mice to $87.09 \%$ and $80.65 \%$ (200 and $300 \mathrm{mg} / \mathrm{kg}$ respectively) compared to the standard indomethacin (70.97\%). The extracts (200 and $300 \mathrm{mg} / \mathrm{kg}$ respectively) also significantly $(p<0.001)$ reduced the writhing to $43.39 \%, 64.15 \%$ in early and $46.15 \%, 97.44 \%$ in late phase of formalin-induced licking and biting. In 2,4-DNP induced pyrexia the extracts exhibited protection at 200 and $400 \mathrm{mg} / \mathrm{kg}$, similar to standard drug aspirin at $150 \mathrm{mg} / \mathrm{kg}$.

Conclusion: The results demonstrated that the plant extract has potential CNS depressant, analgesic and antipyretic activity.

Keywords: CNS depressant, Analgesic, Antipyretic, Proximate analysis, Lathyrus sativus L

\section{Background}

Several herbal plants have been listed in the ancient literatures for their different medicinal values and their formulation has been found to be effective for the treatment of various diseases [1]. Medicinal plants have provided us lots of bioactive natural compounds like alkaloids, carbohydrates, glycosides, saponins, flavonoids,

\footnotetext{
*Correspondence: abhijitdas@nstu.edu.bd; abhi.nstu@gmail.com ${ }^{2}$ Department of Pharmacy, Noakhali Science and Technology University, Noakhali 3814, Bangladesh

Full list of author information is available at the end of the article
}

phenolic compounds, steroids, tannins, gum, amino acids and volatile oils having a wide range of therapeutic and pharmacological potentials which are being used as raw materials for new drug discovery and development for different ailment $[2,3]$.

Depression of central nervous system (CNS) can be considered as a major affective brain disorder which is very prevalent now-a-days as about $5 \%$ of the general population is found to be suffering from it [4]. For the treatment of this disorder several antipsychotic drugs are available in the local medicine stores. But these 
drugs are reported to be hazardous to human health as they exhibit side effects like damage of autonomic, endocrine, haematopoietic systems, neurological impairment and allergic reactions [5]. Analgesics can be described as those substances which reduces the sensation of pain by alleviating pain threshold to external stimuli [6]. Contemporary analgesics like opiates and non-steroidal anti-inflammatory medications might not continually be appropriate for all patients, significantly for those with chronic pain, because of the limitations of efficacy, facet effects and intolerability. Pyrexia or fever occurs as a result of secondary implication of inflammation while enhanced production of prostaglandins is the key factor for the induction of pain, inflammation and fever [7]. Thus, most anti-inflammatory agents are also expected to possess analgesic and antipyretic activities as they inhibit or prevent excess production of prostaglandins [8]. Based on the above adverse effects of various commercial drugs there is a high demand for these arches of new drugs with lesser or no side effects. Therefore, researchers are focusing towards traditional complementary and alternative medicines to discover new drugs for the treatment of psychiatric disorders, alleviating pain and fever [9-11].

Lathyrus sativus L. (grass pea), belonging to Fabaceae family and locally known as "Khesari" in Bangladesh, is widely cultivated for human consumption and livestock feed in Asia and East Africa [12]. The seeds of L. sativus L. contain 28 to $32 \%$ of proteins and essential amino acids [13]. Oil extracted from the seeds of L. sativus L. are used locally as homeopathic medicine [14]. It is also used as traditional medicine in Bangladesh to cure Scabies, eczema, and allergy [15]. It was reported by several studies that the seeds of $L$. sativus L. possess antioxidant [16] and hypoglycemic activities [17] yet no research has been conducted regarding CNS depressant, analgesic and antipyretic activities of the plant extract. Therefore, in pursuit of searching plants possessing significant medicinal and pharmacological activities in Bangladesh and for finding out new sources of CNS depressor, analgesics and anti-inflammatory agents, here we have analyzed the crude methanolic extract of $L$. sativus L. seeds for its CNS depressant, analgesic and antipyretic activities and reported the results in our preliminary investigation.

\section{Methods}

\section{Drugs and chemicals}

All the chemicals used in this study were of analytical grade, and purchased from Sigma Chemical Co. (St. Louis, MO, USA), and Merck (Darmstadt, Germany). Diazepam (Incepta Pharmaceuticals Ltd.), Indomethacin (Opsonin Pharma Ltd.), Aspirin (Square Pharmaceuticals Ltd.) was used for conducting the tests.

\section{Collection and extraction of plant material}

The L. sativus L. seeds were collected from the Noakhali region, Bangladesh. The plant samples were identified by a taxonomist and a taxonomical sample specimen (DACB: 36575) was preserved in the National Herbarium of Bangladesh for future reference. The plant seeds were grounded into powder and $500 \mathrm{~g}$ of the sample was soaked in $99 \%$ methanol. The mixture was then filtrated and the extraction was concentrated using a rotary evaporator (RE200, Bibby Sterling, Ltd., UK) under reduced pressure at $4 \mathrm{rpm}$ and $65{ }^{\circ} \mathrm{C}$ temperature. The gummy concentrate obtained was designated as crude methanolic extract. The crude methanolic extract was further freeze dried and preserved at $+4{ }^{\circ} \mathrm{C}$ for further analysis.

\section{Test animals}

Healthy Swiss albino mice, six weeks of age and weighing about 25-30 g, of both sexes were obtained from the central animal house of the Department of Pharmacy, Jahangirnagar University, Savar, Dhaka-1342, Bangladesh. The mice were housed five per cage and acclimatized in standard laboratory conditions (room temperature $24 \pm$ $2{ }^{\circ} \mathrm{C}$, relative humidity $55-60 \%$, and $12 \mathrm{~h}$ light and dark cycles) for 7 days and were fed formulated rodent food and water prior to the research work. The study was conducted following all the rules governing the use of laboratory animals. The experimental protocol was approved by the Animal Ethics Committee of Noakhali Science and Technology University, Bangladesh.

\section{Proximate analysis and phytochemical screening}

The parameters determined for proximate analyses include moisture, ash content, crude protein and fat. The analysis was carried out using the modified method described by [18] based on method of Association of Official Analytical Chemists (AOAC, 1990). The preliminary phytochemical evaluation of the plant extract for alkaloids, carbohydrates, reducing sugar, cardiac glycosides, flavonoids, saponins, phytosterols, terpenes, phenols, proteins and amino acids, tannins and steroids were determined by using the standard procedures [19-21].

\section{Experimental design}

The experimental animals were divided into control, standard and two test groups containing five mice each. For all test, Group-1 served as controls, Group-2 for standard and Group-3, Group-4 received experimental plant extract. Group 1 received the vehicle 1\% Tween 80 in water (at the dose of $10 \mathrm{ml} / \mathrm{kg}$ body weight), group 2 received various standard drugs like Diazepam, Indomethacin, Aspirin at different doses [22-24], and group 3 and 4 received $200-400 \mathrm{mg} / \mathrm{kg}$ dose of plant extract on the basis of toxicity study of the plant extract. 


\section{CNS depressant activity test Open field test}

This experiment was carried out in accordance with a modified method of Adebesin et al. [25].. The mice in the control group received the vehicle $1 \%$ Tween 80 in water (at the dose of $10 \mathrm{ml} / \mathrm{kg}$ body weight) while the test groups received the crude methanolic extract of $L$. sativus L. seeds (at the doses of 200 and $300 \mathrm{mg} / \mathrm{kg}$ body weight respectively) and standard group received diazepam at the dose of $10 \mathrm{mg} / \mathrm{kg}$ body weight (b.w.) orally. The animals were placed on the floor of an open field $(100 \mathrm{~cm} \times$ $100 \mathrm{~cm} \times 40 \mathrm{~cm} \mathrm{~h}$ ) divided into a series of squares with alternative color (black and white). The number of squares visited by each animal was counted for 3 min duration started at 0, 30, 60, 90 and 120 min after the administration of test drugs.

\section{Hole-cross test}

The method described by Hussain et al. was followed to conduct this test using a cage $(30 \mathrm{~cm} \times 20 \mathrm{~cm} \times 14 \mathrm{~cm})$ with a steel partition fixed in the middle [26]. A hole of $3 \mathrm{~cm}$ diameter was made at a height of $7.5 \mathrm{~cm}$ in the middle of the cage. The mice were divided into control (received vehicle $1 \%$ Tween 80 in water at $10 \mathrm{~mL} / \mathrm{kg}$ body weight), standard (diazepam at a dose of $1 \mathrm{mg} / \mathrm{kg}$ body weight) and two test groups (received methanolic extract of seeds of $L$. sativus L. at the doses of 200 and $300 \mathrm{mg} / \mathrm{kg}$ body weight respectively) each having five mice. The number of passage of a mouse from one chamber to another through the hole was recorded for a period of $3 \mathrm{~min}$ at the 0, 30, 60, 90 and $120 \mathrm{~min}$ of the oral administration of test drugs.

\section{In vivo analgesic activity test}

\section{Acetic acid induced writhing test}

To evaluate the analgesic activity of the plant extract acetic acid writhing model in mice was conducted accordingly the procedure described by Koster et al. [27]. The test samples (methanolic extract of L. sativus L., 200 and $400 \mathrm{mg} / \mathrm{kg}$ body weight respectively), standard (indomethacin, $10 \mathrm{mg} / \mathrm{kg}$ body weight per orally) and control (1\% Tween 80 in distilled water at the dose of $10 \mathrm{ml} / \mathrm{kg}$ body weight) were given and after $30 \mathrm{~min} 0.7 \%$ acetic acid was injected intra-peritoneally (i.p.). The writhing (constriction of abdomen, turning of trunk and extension of hind legs) was observed randomly after $15 \mathrm{~min}$ of interval and its frequency was counted for up to $25 \mathrm{~min}$ in each group of animals. The percent inhibition (\% analgesic activity) was calculated by:

$$
\% \text { Inhibition }=[(\mathrm{A}-\mathrm{B}) / \mathrm{A}] \times 100
$$

Where, $\mathrm{A}=$ Average number of writhing of the control group; $\mathrm{B}=$ Average number of writhing of the test or standard groups.

\section{Formalin induced writhing test}

This test was performed according to the procedure described by Viana et al. [28]. The experimental animals were separated in four groups each having 5 mice and received 1\% Tween 80 in water at $10 \mathrm{ml} / \mathrm{kg}$ body weight dose per orally (p.o.) (control group), indomethacin at $10 \mathrm{mg} / \mathrm{kg}$ body weight subcutaneously (s.c.) (standard) and methanolic extract of L. sativus L. seeds at the dose of 200 and $400 \mathrm{mg} / \mathrm{kg}$ body weight p.o. (test groups). At $30 \mathrm{~min}$ interval the test animals were injected $50 \mu \mathrm{L}$ of freshly prepared $0.6 \%$ solution of formalin subcutaneously, under the plantar surface of the left hind paw of each mouse. The mice were placed individually in an observation chamber and monitored for one hour. The time (in second) spent in licking and biting responses of the injected paw was taken as an indicator of pain response. Anti-nociceptive effect was determined in two phases. The early phase (Neurogenic phase) was recorded during the first $5 \mathrm{~min}$, while the late phase (Inflammatory phase) was recorded during the last15-20 min after formalin injection.

\section{Antipyretic activity test 2,4-Dinitrophenol (DNP) induced pyrexia}

Adult albino mice of both sexes fasted for $24 \mathrm{~h}$ but allowed water ad libitum were used for the experiment. They were randomized into groups of five mice each. DNP $(10 \mathrm{mg} / \mathrm{kg}$, i.p.) was administered to the mice after obtaining the basal rectal temperatures. Hyperthermia developed within 30 min of DNP administration. Different doses of extract (200 and $400 \mathrm{mg} / \mathrm{kg}$ body weight i.p.), aspirin $(150 \mathrm{mg} / \mathrm{kg})$, and distilled water $(10 \mathrm{ml} / \mathrm{kg}$, p.o.) were administered to the treatment and control groups of animals. The rectal temperature of each animal was recorded by inserting a thermometer $2 \mathrm{~cm}$ into the rectum at 1, 2, 3 and $4 \mathrm{~h}$ after administration of the test drugs [29].

\section{Statistical analysis}

One way ANOVA with Dunnett's post Hoc test for this experiment was carried out with SPSS 18.0 for Windows $^{\oplus}$ software and the results obtained were compared with the control group. Differences between groups were considered significant at a level of $p<0.001, p<0.01$ and $p<0.05$.

\section{Results}

\section{Proximate analysis}

Results of proximate analysis of dried seeds of $L$. sativus L. are demonstrated in Table 1 . The results revealed that the plant extract has low moisture content $(10.77 \%)$ and a high ash value $(6.68 \%)$. It also contains moderate concentration of protein $(4.27 \%)$ and low concentration of fat $(1.11 \%)$. 
Table 1 Proximate composition of dried L. sativus L. seeds

\begin{tabular}{ll}
\hline Proximate Analysis & Value (\%) \\
\hline Moisture Content & 10.77 \\
Total Ash Value & 6.68 \\
Proteins & 4.27 \\
Fat & 1.11 \\
\hline
\end{tabular}

\section{Phytochemical screening}

Table 2 reveals the quantitative phytochemical analysis of L. sativus L. seeds. The preliminary phytochemical evaluation of the plant extract confirmed the presence of alkaloids, carbohydrates, reducing sugar, flavonoids, terpenes, phenols, proteins and amino acids, and tannins.

\section{CNS depressant activity Open field test}

After statistical analysis of the experimental data (Dunnett's test), it was observed that in open field test, the number of squares traveled by the mice was suppressed significantly in the test group throughout the study period (Table 3 ). The CNS depressant activity observed for the extract was dose dependent and a noticeable result was found at $120 \mathrm{~min}$ of test sample administration. Test animals showed significant $(p<0.001)$ decrease in number of movement at the dosages of $300 \mathrm{mg} / \mathrm{kg}(2.67$ $\pm 0.33)$ and $200 \mathrm{mg} / \mathrm{kg}(9.33 \pm 0.33)$, as compared to $34.67 \pm 2.60$ for the control group and $24.00 \pm 1.53$ for the standard group after $120 \mathrm{~min}$ of administration of the extract.

\section{Hole-cross test}

Results of the hole-cross test of L. sativus L. seeds are shown in Table 4. The locomotors activity reducing effect was manifested at the 2 nd observation (30 $\mathrm{min})$

Table 2 Phytochemical compositions of methanolic extract of $L$. sativus L. seeds

\begin{tabular}{ll}
\hline Phytochemical groups & Methanolic extract \\
\hline Alkaloids & + \\
Carbohydrates & + \\
Reducing Sugar & + \\
Cardiac Glycosides & - \\
Flavonoids & + \\
Saponins & - \\
Phytosterols & - \\
Terpenes & + \\
Phenols & + \\
Proteins and Amino acids & + \\
Tannins & + \\
Steroids & -
\end{tabular}

$(+)=$ Present of Phytochemicals and $(-)=$ Absence of Phytochemicals period and was sustained up to the 5th observation period $(120 \mathrm{~min})$ for the plant extract. The extract diminished the movement of the tested animals in a dose dependent manner which was comparable with standard diazepam. After 120 min of administration the extract, at the dose of 200 and $300 \mathrm{mg} / \mathrm{kg}$, showed significant ( $p$ $<0.001)$ depressant activity by reducing the locomotion of the mice to $2.50 \pm 0.64(p<0.001)$ and $1.25 \pm 0.25(p$ $<0.001)$ respectively. In comparison the standard drug diazepam reduced the movement of the tested animal to $2.50 \pm 0.29(p<0.001)$ at the dose of $1 \mathrm{mg} / \mathrm{kg}$.

\section{Analgesic activity \\ Acetic acid induced writhing method}

The results showed that the pain relief was achieved in a significant $(P<0.01, P<0.001)$ dose dependent manner, at all test doses (200 and $400 \mathrm{mg} / \mathrm{kg}$ body weight) as shown in figs. 1 and 2 ensured by Dunnett's test. Maximum writhing inhibition (87.09\%) was observed at $400 \mathrm{mg} / \mathrm{kg}$ dose of methanolic extract of L. sativus L. seeds while at $300 \mathrm{mg} / \mathrm{kg}$ dose it exhibited $80.65 \%$ inhibition. The inhibitory effect of indomethacin $(10 \mathrm{mg} / \mathrm{kg}$ body weight) was lower (70.97\%) than that of the highest dose of the plant extract.

\section{Formalin induced paw licking method}

The results of the antinociceptive effects of L. sativus L. seeds on formalin-induced paw pain response in mice are presented in Table 5 . It can be seen that the highest dose $(400 \mathrm{mg} / \mathrm{kg}$ b.w.) caused a significant $(p<0.001)$ inhibitory effect, once again in a dose dependent manner, on both phases of formalin induced pain as compared to control. The percentage of inhibition was 43.39 and $46.15 \%$ for the dose of $200 \mathrm{mg} / \mathrm{kg}$; and 64.15 and $97.44 \%$ for $450 \mathrm{mg} / \mathrm{kg}$ b.w. in the first and second phase respectively. This potency was comparable to that of indomethacin $(10 \mathrm{mg} / \mathrm{kg}$ b.w.) which produced an inhibition of $54.72 \%$ during the first phase and $71.79 \%$ during the second phase of the formalin-induced pain in mice.

\section{Antipyretic activity \\ 2, 4-Dinitrophenol (DNP) induced pyrexia test}

From the results (Table 6), it was observed that, experimental mice showed a marked increase in rectal temperature, 18th $\mathrm{h}$ after DNP injection. The extract (200 and $400 \mathrm{mg} / \mathrm{kg})$ significantly $(p<0.05-0.01)$ reduced the rectal temperature of the animals in the second, third and fourth hour after administration, reaching the peak of antipyretic effect with the highest dose $(400 \mathrm{mg} / \mathrm{kg})$ in the 4 th $\mathrm{h}\left(35.26 \pm 0.52{ }^{\circ} \mathrm{C}, p<0.001\right)$, in relation to control $\left(36.95 \pm 0.49{ }^{\circ} \mathrm{C}\right)$. Standard drug (aspiring) treatment $(150 \mathrm{mg} / \mathrm{kg}$ body weight) caused significant $(p<0.05)$ antipyretic effect at all time periods, 
Table 3 Effect of methanolic extract of the L. sativus L. seeds on open field test in mice

\begin{tabular}{|c|c|c|c|c|c|}
\hline \multirow[t]{2}{*}{ Group } & \multicolumn{5}{|c|}{ Number of Movements(Mean \pm SEM) } \\
\hline & $0 \mathrm{~min}$ & $30 \mathrm{~min}$ & $60 \mathrm{~min}$ & $90 \mathrm{~min}$ & $120 \mathrm{~min}$ \\
\hline Group-l & $57.50 \pm 2.50$ & $50.50 \pm 2.50$ & $46.67 \pm 1.76$ & $45.33 \pm 5.33$ & $34.67 \pm 2.60$ \\
\hline Group-II & $45.00 \pm 2.00$ & $33.00 \pm 2.00^{*}$ & $31.33 \pm 2.03^{* *}$ & $15.33 \pm 0.88^{* *}$ & $24.00 \pm 1.53^{* *}$ \\
\hline Group-III & $38.50 \pm 1.50^{* *}$ & $32.50 \pm 2.50^{*}$ & $32.00 \pm 2.00^{* *}$ & $23.33 \pm 1.45^{*}$ & $9.33 \pm 0.33^{* * *}$ \\
\hline Group-IV & $36.50 \pm 0.50$ & $29.50 \pm 0.50^{*}$ & $20.67 \pm 3.04^{* *}$ & $4.33 \pm 0.33^{* *}$ & $2.67 \pm 0.33^{* * *}$ \\
\hline
\end{tabular}

Values are represented as mean $\pm \mathrm{SEM},(n=5)$. Group I (control) animals received vehicle ( $1 \%$ Tween 80 in water), Group II (standard) received diazepam $1 \mathrm{mg} / \mathrm{kg}$ body weight, Group III and Group IV were treated with 200 and $300 \mathrm{mg} / \mathrm{kg}$ body weight (p.o.) of the methanolic extract of $L$. sativus L. seeds, respectively.

***indicates $P<0.001$, **indicates $P<0.01$ and *indicates $P<0.05$; one-way ANOVA followed by Dunnett's test as compared to control

reaching the peak in the 4 th $\mathrm{h}\left(35.00 \pm 0.49^{\circ} \mathrm{C}\right)$ in comparison to control.

\section{Discussion}

In our research work we tried to explicate diverse pharmacological potency of the methanolic extract of $L$. sativus L. in mice along with the proximate and phytochemical analysis. The proximate analysis of the plant extract was carried out to evaluate its moisture, total ash, protein and fat content. It is a very important technique for the product development and quality control or regulatory purposes in the food industry and also for the purity and quality test of crude drugs in pharmaceutical industry [30]. Our study results demonstrated that the methanolic plant extract had a low moisture content which indicates that the preservation period of the extract will be high as it is evident that moisture content in the range of $5-15 \%$ are good for formulating and also hinder the microbial growth [31]. The moderate amount of ash content in the plant extract suggests that it is comparatively rich in different types of minerals. Ash content estimation is necessary because the inorganic elements or minerals may be the cause of a pharmacological impact [32]. Proximate analysis also revealed that the plant possess moderate amount of protein and lower amount of fat. Protein plays a major role in various body functions like body development, fluid balance, hormone and enzyme formation and also sustaining strong immune function. While low content of fat (below the range $8.3-27.0 \%$ ) is reported to be poor sources of lipids and thus increase in the consumption of the vegetables would naturally lower fat intake [32].
The secondary metabolites (phytochemicals) of a plant extract are responsible for the pharmacological actions of that plant or plant parts and thus estimation of those bioactive compounds may be used to treat chronic as well as infectious diseases [30]. Our study was an evidential approach to ascertain the mentioned pharmacological functions of L. sativus L. seeds and found to have the presence of alkaloids, carbohydrates, reducing sugar, flavonoids, terpenes, phenols, proteins and amino acids, and tannins in the plant extract. Several studies reported that alkaloids possess various pharmacological activities like antihypertensive, antiarrhythmic, antimalarial and anticancer activity [33]. Pure alkaloids and their synthetic compounds have also been reported to be used as analgesic, antispasmodic and antibacterial agents [32]. Carbohydrates and reducing sugar are essential nutrient for the body as they produce energy required and supplies energy to brain, muscle and blood [34]. Terpenes possess medicinal properties such as anticarcinogenic, antimalarial, antiulcer, antimicrobial and diuretic activity [32]. Phenols, flavonoids and tannins are the major groups responsible for antioxidant activity [31]. Previous studies showed that saponins demonstrated antibacterial, antiinflammatory, anticancer, and antidiabetic activities [35].

Two different neuropharmacological models, namely open field and hole-cross test, were used to study the CNS depressant activity of $L$. sativus L. seed extract. The results of the study provided evidence that the plant extract significantly $(p<0.001)$ induced sedative-hyponotic activity in test animals confirming their CNS depressant

Table 4 Effect of methanolic extract of the L. sativus L. seeds on hole cross test in mice

\begin{tabular}{|c|c|c|c|c|c|}
\hline \multirow[t]{2}{*}{ Group } & \multicolumn{5}{|c|}{ Number of Movements (Mean \pm SEM) } \\
\hline & $0 \mathrm{~min}$ & $30 \mathrm{~min}$ & $60 \mathrm{~min}$ & $90 \mathrm{~min}$ & $120 \min$ \\
\hline Group-I & $11.75 \pm 1.11$ & $27.00 \pm 2.45$ & $19.50 \pm 2.22$ & $18.50 \pm 1.19$ & $20.00 \pm 2.39$ \\
\hline Group-II & $6.50 \pm 1.32^{*}$ & $11.00 \pm 1.58^{* *}$ & $5.25 \pm 1.37^{* *}$ & $9.00 \pm 0.58^{* * *}$ & $2.50 \pm 0.29^{* * *}$ \\
\hline Group-III & $2.25 \pm 0.48^{* * *}$ & $9.50 \pm 1.08^{* *}$ & $6.25 \pm 1.03^{* *}$ & $4.00 \pm 0.41^{* * *}$ & $2.50 \pm 0.64^{* * *}$ \\
\hline Group-IV & $4.00 \pm 0.91^{* *}$ & $6.50 \pm 0.87^{* * *}$ & $4.00 \pm 0.71^{* * *}$ & $2.25 \pm 0.29^{* * *}$ & $1.25 \pm 0.25^{* * *}$ \\
\hline
\end{tabular}

Values are represented as mean \pm SEM, $(n=5)$. Group I (control) animals received vehicle (1\% Tween 80 in water), Group II (standard) received diazepam $1 \mathrm{mg} / \mathrm{kg}$ body weight, Group III and Group IV were treated with 200 and $300 \mathrm{mg} / \mathrm{kg}$ body weight (p.o.) of the methanolic extract of L. sativus L. seeds, respectively.

***indicates $P<0.001$, **indicates $P<0.01$ and *indicates $P<0.05$; one-way ANOVA followed by Dunnett's test as compared to control 


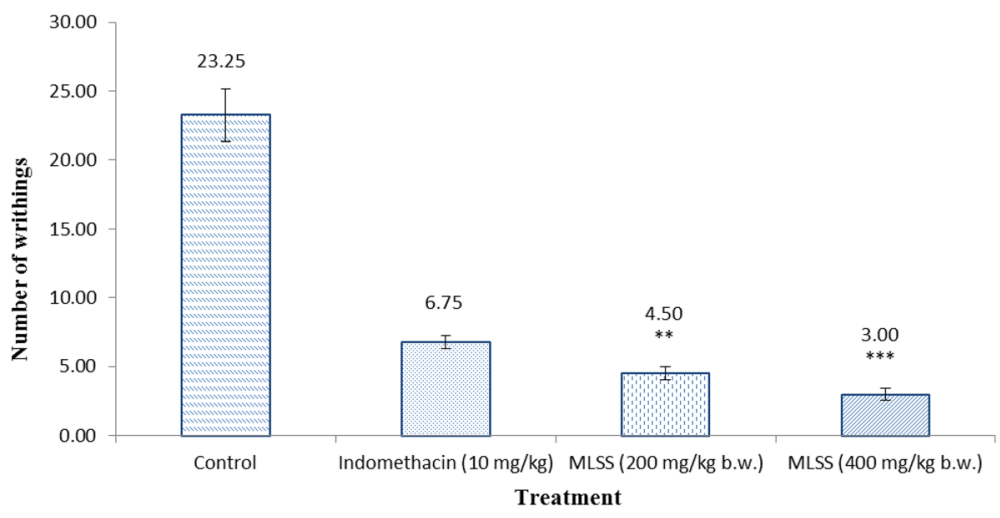

Fig. 1 Effect of $L$. sativus $L$. seeds on acetic acid induced writhing in mice. Results are given as mean $\pm S E M$ of five animals in each group. ***indicates $P<0.001$, **indicates $P<0.01$ when compared to control. One-way ANOVA followed by Dunnett's test as compared to control. MLSS = Methanolic extract of L. sativus L. seeds

activity. Gamma-aminobutyric acid (GABA) is evidenced to be the major inhibitory neurotransmitter of CNS and several anxiolytic, muscle relaxant and sedative-hypnotic drugs exhibit their action via GABA [36]. Thus it can be pretended that the methanolic seed extract may act by commencing the GABAergic inhibition of the CNS through membrane hyperpolarization that lead to a reduction in the firing rate of critical neurons in the brain or the extract may simply activate the GABA receptors directly [37]. Again, research has shown that plants containing alkaloids, flavonoids and tannins are useful for the treatment of many CNS disorders as they reduce the locomotor activity of the CNS [38] which led to the postulation that these compounds may act as benzodiazepine like molecules [39]. Earlier investigation of the phytoconstituents of L. sativus L. proved the presence of these phytochemicals [40]. Thus it may be predicted that these compounds may also be responsible for the CNS depressant activity of the plant extracts though the key compound for producing such effect is yet to be discovered.
Among various available test to evaluate the analgesic activity of different compounds, Acetic acid-induced writhing is a well recommended protocol in evaluating the peripheral analgesic property of medicinal agents due to its sensitivity and response to the compounds at a dose which is not effective in other methods [41]. In our study, assessment of analgesic activity using the acetic acid induced writhing test revealed that oral administration of $L$. sativus L. seeds produced a statistically significant inhibition of writhes compared to the control. This is an indication of the peripheral analgesic activity of the active principle(s) of the plant extract, since any agent that lowers the writhing number, demonstrates analgesia by inhibiting prostaglandin synthesis which is a peripheral mechanism of pain inhibition [42]. Here the pain induction is caused by liberating endogenous substances as well as some other pain mediators such as arachidonic acid via cyclooxygenase, and prostaglandin biosynthesis (specifically lipoxygenase, PGE2 and PGF2 $\alpha$ ) [43]. These products enhance capillary permeability affecting local pain receptor that results in inflammation and pain [41].

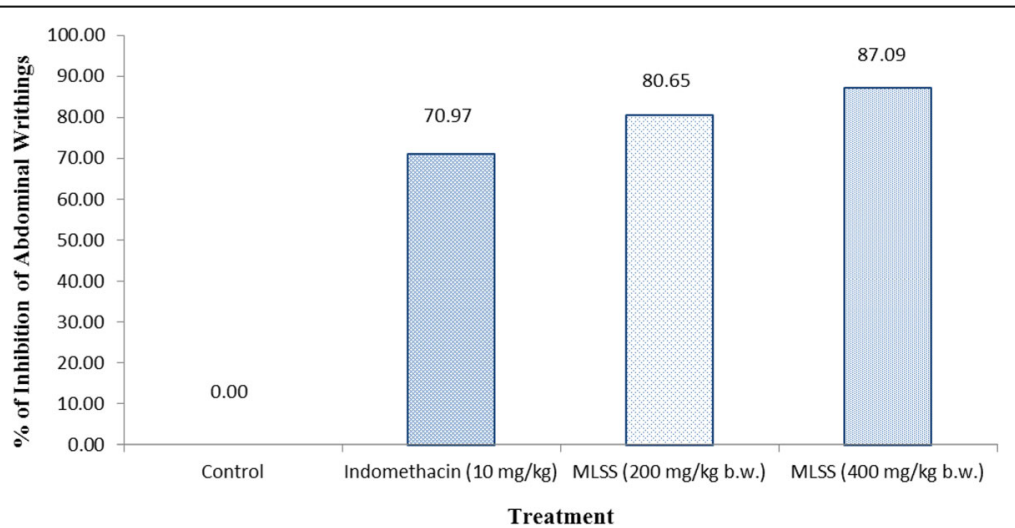

Fig. 2 Percentage of inhibition of abdominal contractions in acetic acid induced writhing method by L. sativus L. seeds and standard indomethacin. MLSS = Methanolic extract of L. sativus L. seeds 
Table 5 Effect of methanolic extract of the L. sativus L. seeds on formalin induced writhing in mice

\begin{tabular}{|c|c|c|c|c|}
\hline \multirow[t]{2}{*}{ Groups } & \multicolumn{2}{|c|}{ Licking number (Mean \pm SEM) } & \multicolumn{2}{|l|}{$\%$ Inhibition } \\
\hline & Early phase (0-5 min) & Late phase (10-15 min) & Early phase $(0-5 \mathrm{~min})$ & Late phase (10-15 min) \\
\hline Group-l & $13.25 \pm 0.63$ & $9.75 \pm 0.85$ & - & - \\
\hline Group-II & $6.00 \pm 0.41$ & $2.75 \pm 0.25$ & 54.72 & 71.79 \\
\hline Group-III & $7.50 \pm 0.65^{* *}$ & $5.25 \pm 0.63^{* *}$ & 43.39 & 46.15 \\
\hline Group-IV & $4.75 \pm 0.48^{* *}$ & $0.25 \pm 0.25^{* * *}$ & 64.15 & 97.44 \\
\hline
\end{tabular}

Values are expressed as mean \pm SEM $(n=5)$. Group I (control) animals received vehicle (1\% Tween 80 in water), Group II (standard) received indomethacin 10 mg/ $\mathrm{kg}$ body weight, Group III and Group IV were treated with 200 and $400 \mathrm{mg} / \mathrm{kg}$ body weight (p.o.) of the methanolic extract of $L$. sativus L. seeds, respectively. ${ }^{* * *}$ indicates $P<0.001$, and ${ }^{* *}$ indicates $P<0.01$; one-way ANOVA followed by Dunnett's t-test as compared to control. MLSS $=$ Methanolic extract of $L$. sativus L. seeds

In order to obtain more specific evidence on the possible mechanism of analgesic activity of L. sativus $\mathrm{L}$. seeds, the effect of different doses of the plant extract on formalin test was examined. This test model is considered as a method of persistent pain produced by the intra-plantar injection of formalin that induces a biphasic nociceptive behavior. The early phase $(0-5 \mathrm{~min})$ is characterized by neurogenic pain caused by $\mathrm{C}$-fibre activation due to the stimulation of peripheral nociceptors caused by formalin [44]. A second burst of licking behavior occurs after 15 to $30 \mathrm{~min}$ and seems to be characterized by the inflammatory response elicited by formalin which is triggered by a combination of stimuli, including inflammation of the peripheral tissues and mechanisms of central sensitization $[45,46]$. Again it is assumed that manifestation in the late phase is due to inflammation causing a release of serotonin, histamine, bradykinin and prostaglandins, which at least to some degree can cause the sensitization of the central nociceptive neurons [47]. It is reported that substance $\mathrm{P}$ is involved in the first phase whereas histamine, serotonin, prostaglandins and bradykinin are responsible for the second phase of inflammation [45]. In our research, the extract demonstrated antinociceptive activity in blocking both phases of the formalin response although the effect of the extract was more pronounced in the late phase of test. As oral pretreatment with $L$. sativus $\mathrm{L}$. inhibited the first (neurogenic pain) and second (inflammatory nociception) phases of formalin-induced licking in mice therefore it may be postulated that the plant extract may possess both peripheral and central effect.
On antipyretic activity the plant extract significantly inhibited DNP induced pyrexia at both the concentrations. In generally, non-steroidal anti-inflammatory drugs (NSAIDs) exhibit their antipyretic effect through inhibiting the production of prostaglandins specifically prostaglandin E2 (PGE2) in the hypothalamus [48]. Thus it may be assumed that the plant extract may have functioned as a cyclooxygenase-2 (COX-2) antagonist through the inhibition of PGE2 production in the hypothalamus or by the enhancement of body's own antipyretic substances such as vasopressin and arginine production [29, 48]. Furthermore, the extract could have also been mediated its hypothermic activity by vasodilatation of superficial blood vessels resulting in increased dissipation of heat following resetting of hypothalamic temperature control center [49]. However, all these actions may be due to presence of certain phytochemical compounds in this plant as several studies have reported that steroids, tannins, triterpenoids, flavonoid and coumarin glycosides are responsible for antipyretic activity [50]. Our investigated plant also contains tannis, terpenoids and flavonoid which may have attributed to its potent antipyretic activity.

\section{Conclusion}

On the basis of the findings of the present study it can be easily stated that the methanolic extract of Lathyrus sativus L. seeds possesses remarkable pharmacological potentialities. The results of our research work also supplicate its traditional uses for various medical purposes. Therefore, the experimental evidence obtained in the

Table 6 Effect of methanol extract of L. sativus L. seeds on 2, 4-Dinitrophenol (DNP) induced pyrexia in mice

\begin{tabular}{lllllll}
\hline Treatment & \multicolumn{5}{l}{ Temperature in ${ }^{\circ} \mathrm{C}$} & \multicolumn{5}{l}{} \\
\cline { 2 - 7 } & Initial & Pyretic & $1 \mathrm{~h}$ & $2 \mathrm{~h}$ & $3 \mathrm{~h}$ & $4 \mathrm{~h}$ \\
\hline Group-I & $36.23 \pm 0.69$ & $37.23 \pm 0.55$ & $37.22 \pm 0.54$ & $37.01 \pm 0.5$ & $37.01 \pm 0.50$ & $36.95 \pm 0.49$ \\
Group-II & $34.95 \pm 0.28$ & $36.09 \pm 0.22$ & $35.79 \pm 0.30^{*}$ & $35.24 \pm 0.29^{*}$ & $35.08 \pm 0.27^{*}$ & $35.00 \pm 0.28^{*}$ \\
Group-III & $35.97 \pm 0.73$ & $36.93 \pm 0.78$ & $36.79 \pm 0.76$ & $36.41 \pm 0.82$ & $36.29 \pm 0.77$ & $36.22 \pm 0.82$ \\
Group-IV & $34.86 \pm 0.13$ & $36.09 \pm 0.19$ & $35.87 \pm 0.13$ & $35.25 \pm 0.16^{*}$ & $35.08 \pm 0.14^{*}$ & $34.87 \pm 0.13^{* *}$ \\
\hline
\end{tabular}

Values are expressed as mean \pm SEM $(n=5)$. Group I (control) animals received distilled water (10 ml/kg), Group II (standard) received aspirin $150 \mathrm{mg} / \mathrm{kg}$ body weight, Group III and Group IV were treated with 200 and $400 \mathrm{mg} / \mathrm{kg}$ body weight (p.o.) of the methanolic extract of $L$. sativus L. seeds, respectively. ${ }^{* * *}$ indicates $P$ $<0.001$, and ${ }^{* *}$ indicates $P<0.01$; one-way ANOVA followed by Dunnett's t-test as compared to control. MLSS $=$ Methanolic extract of $L$. sativus L. seeds 
laboratory test model could justify for the traditional use of this plant as a CNS depressant, analgesic, and antipyretic agent.

\section{Abbreviations}

AOAC: Association of Official Analytical Chemists; b.w.: Body Weight; CNS: Central Nervous System; COX-2: Cyclooxygenase-2; DNP: Dinitrophenol; GABA: Gamma-aminobutyric acid; i.p.: Intra-Peritoneally; NSAID: Non-Steroidal Anti-Inflammatory Drug; p.o.: Per Orally; PGE2: Prostaglandin E2; s.o.: Subcutaneously

\section{Acknowledgements}

The authors are also thankful to all the teachers and staffs of the Department of Pharmacy, Noakhali Science and Technology University for their cordial co-operation by providing laboratory support to carry out the research work.

\section{Funding}

This research work was carried out by the author in the partial fulfillment of the requirements for the degree of Bachelor of Science (Hons) in Applied Chemistry and Chemical Engineering. Authors did not receive any funding for conducting the research work.

\section{Availability of data and materials}

The datasets analyzed during the current study are available from the corresponding author on request.

\section{Authors' contributions}

MAW and KB carried out the collection of plant, extraction process and conducted the research work. AD wrote the manuscript. SB and $A D^{*}$ carried out conception and design of the study, statistical analysis and interpretation of data. SB and SRD helped in the plant collection procedure, revised the manuscript and guided to improve the quality of final manuscript. All authors read and approved the final manuscript.

\section{Ethics approval and consent to participate}

This study was approved by ethical research committee of Noakhali Science and Technology University, Bangladesh.

\section{Consent for publication}

Not applicable.

\section{Competing interests}

The author reports no conflict of interests in this work.

\section{Author details}

'Department of Applied Chemistry and Chemical Engineering, Noakhali Science and Technology University, Noakhali 3814, Bangladesh. ${ }^{2}$ Department of Pharmacy, Noakhali Science and Technology University, Noakhali 3814, Bangladesh. ${ }^{3}$ Department of Environmental Science and Disaster Management, Noakhali Science and Technology University, Noakhali 3814, Bangladesh.

Received: 19 March 2018 Accepted: 5 July 2018

\section{Published online: 22 August 2018}

\section{References}

1. Senthilkumar R, Ahmedjohn S, Archunan G, Manoharan N. Antioxidant activity of Wedelia chinensis in alloxan induced diabetic rats. Pharmacologyonline. 2008;2:640-51.

2. Hasan MM, Hossain A, Shamim A, Rahman MM. Phytochemical and pharmacological evaluation of ethanolic extract of Lepisanthes rubiginosa $L$ leaves. BMC Complement Altern Med. 2017;17(1):496.

3. Akinmoladun AC, Ibukun EO, Afor E, Obuotor EM, Farombi EO. Phytochemical constituent and antioxidant activity of extract from the leaves of Ocimum gratissimum. Sci Res Essays. 2007;2(5):163-6.

4. Hoskeri JH, Venkatarangaiah K, Hanumanthappa SK, Vootla SK, Gadwala M. CNS depressant activity of extracts from Flaveria trinervia spring C. Mohr Phytopharmacol. 2011;1:101-8.

5. Zhang ZJ. Therapeutic effect of herbal extract and constituents in animal models of psychiatric disorders. Life Sci. 2004;75:1659-99.
6. Kumar JP, Shankar NB. Analgesic activity of Mollugo pentaphylla Linn by tail immersion method. Asian J Pharm Clin Res. 2009;2:61-3.

7. Khan MA, Baki A, Al-Bari MA, Hasan S, Mosaddik MA, Rahman MM, et al. Antipyretic activity of roots of Laportea crenulata gaud in rabbit. Res I Med Med Sci. 2007;2(2):58-61

8. Dewanjee S, Maiti A, Sahu R, Dua TK, Mandal SC. Study of anti-inflammatory and antinociceptive activity of hydroalcoholic extract of Schima wallichii bark. Pharm Biol. 2009;47(5):402-7.

9. Selvi PT, Kumar MS, Yaswanth T, Adiyaman E, Anusha PT. Central nervous system depressant activity of aqueous extract of leaves of Azadirachta indica Linn in mice. Asian J Pharm Res. 2012;2:97-9.

10. Sulaiman MR, Zakaria ZA, Chiong HS, Lai SK, Israf DA, Tg TM, et al. Antinociceptive and anti-inflammatory effects of Stachytarpheta jamaicensis (L.) Vahl (Verbenaceae) in experimental animal models. Med Princ Pract. 2009:18:272-9.

11. Ibrahim B, Sowemimo A, van Rooyen A, Van de Venter M. Antiinflammatory, analgesic and antioxidant activities of Cyathula prostrata (Linn.) Blume (Amaranthaceae). J Ethnopharmacol. 2012;141(1):282-9.

12. Ramakrishna V, Rajasekhar S, Reddy LS. Identification and purification of metalloprotease from dry grass pea (Lathyrus sativus L.) seeds. Appl Biochem Biotechnol. 2010;160(1):63.

13. Urga K, Fufa H, Biratu E, Husain A. Evaluation of Lathyrus sativus cultivated in Ethiopia for proximate composition, minerals, $\beta$-ODAP and anti-nutritional components. African J food, Agricul Nutr. Dev. 2005;5(1):1-15.

14. Duke J. Handbook of legumes of world economic importance. Springer Science \& Business Media. 2012;

15. Ahsan S, Jahan R, Ahmad I, Chowdhury H, Rahmatullah M. A survey of medicinal plants used by Kavirajes of Barisal town in Barisal district. Bangladesh American-Eurasian J Sust Agric. 2010;4(2):237-46.

16. Sarmento A, Barros L, Fernandes Â, Carvalho AM, Ferreira IC. Valorization of traditional foods: nutritional and bioactive properties of Cicer arietinum $\mathrm{L}$. and Lathyrus sativus L. pulses. J Sci Food Agric. 2015;95(1):179-85.

17. Sultana A, Rahmatullah M. Antihyperglycemic activity of methanolic extract of non-boiled and boiled Lathyrus sativus L. seeds. J Chem Pharm Res. 2016; 8(8):874-6.

18. Oluduro AO. Evaluation of antimicrobial properties and nutritional potentials of Moringa oleifera lam. Leaf in South_Western Nigeria, Malaysian. J Microbiol. 2012;2(8):59-67.

19. Harborne JB. Phytochemical methods. A guide to modern techniques of plant analysis, vol. 13. London, New York: Chapman and Hall Ltd; 1973. p. 49-188.

20. Roopashree TS, Dang R, Rani SRH, Narendra C. Antibacterial activity of antipsoriatic herbs: Cassiatora, Momordica charantia and Calendula officinalis. Int J Appl Res Nat Prod. 2005;1 (3):20-8.

21. Sofowora AE. Recent trends in research into African medicinal plants. J Ethnopharmacol. 1993;389:209-14.

22. Nahar L, Zahan R, Morshed MTI, Haque A, Alamand Z, Mosaddik A. Antioxidant, analgesic and CNS depressant effects of Synedrella Nodiflora. PHOG J. 2012:4(31):29-36.

23. Murugesan T, Ghosh L, Das J, Pal M, Saha BP. CNS activity of Jussiaea suffruticosa Linn. Extract in rats and mice. Pharm Pharmacol Commun. 1999;5:663-6.

24. Essien AD, Essiet GA, Akuodor GC, Akpan JL, Chilaka KC, Bassey AL, Ezeokpo $B C$, Nwobodo NN. Pharmacological evaluation of the aqueous stem bark extract of Bombax buonopozense in the relief of pain and fever. Afr J Pharm Pharmacol. 2016;10(5):59-65.

25. Adebesin IF, Akindele AJ, Adeyemi OO. Evaluation of neuropharmacological effects of aqueous leaf extract of Albizia glaberrima (Leguminosae) in mice. Ethnopharmacol. 2015;160:101-8.

26. Hussain J, Ur Rehman N, Hussain H, Al-Harrasi A, Ali L, Rizvi TS. Analgesic, anti-inflammatory, and CNS depressant activities of new constituents of Nepeta clarkei. Fitoterapia. 2012;83(3):593-8.

27. Koster R, Anderson M, DeBeer EJ. Acetic acid analgesic screening. Fed Proc. 1959;18:418-20.

28. Viana GS, Do Vale TG, Rao VSN, Matos FJA. Analgesic and antiinflammatory effects of two chemotypes of Lippia alba: a comparative study. Pharm Biol. 1998;36(5):347-51.

29. Okokon J, Davis KA, Azare BA. Antipyretic and antimalarial activities of Solenostemon monostachyus. Pharm Biol. 2016;54(4):648-53.

30. Shukla A, Vats S, Shukla RK. Phytochemical screening, proximate analysis and antioxidant activity of Dracaena reflexa lam. Leaves. Indian J Pharm Sci. 2015;77(5):640. 
31. Islam MZ, Hossain MT, Hossen F, Mukharjee SK, Sultana N, Paul SC. Evaluation of antioxidant and antibacterial activities of Crotalaria pallida stem extract. Clinical Phytosci. 2018;4(1):8.

32. Achi NK, Onyeabo C, Ekeleme-Egedigwe CA, Onyeanula JC. Phytochemical, proximate analysis, vitamin and mineral composition of aqueous extract of Ficus capensis leaves in south eastern Nigeria. J Appl Pharm Sci. 2017;7(3):117-22.

33. Saxena M, Saxena J, Nema R, Singh D, Gupta A. Phytochemistry of medicinal plants. J Pharmacog Phytochem. 2013;1(1):168-82.

34. Ejelonu BC, Lasisi AA, Olaremu AG, Ejelonu OC. The chemical constituents of calabash (Crescentia cujete). African J Biotechnol. 2011;10(84):19631-6.

35. Urzúa A, Rezende MC, Mascayano C, Vásquez L. A structure-activity study of antibacterial diterpenoids. Molecules. 2008;13:882-91.

36. Wong CG, Bottiglieri T, Snead OC. Gaba, Y-hydroxybutyric acid, and neurological disease. Annals Neurol. 2003;54(S6):S3-12.

37. Kolawole OT, Makinde JM, Olajide OA. Central nervous system depressant activity of Russelia equisetiformis. Niger J Physiol Sci. 2007;22:59-63.

38. Hossain MS, Akter S, Das A, Sarwar MS. CNS depressant, antidiarrheal and antipyretic activities of ethanolic leaf extract of Phyllanthus acidus L. on Swiss albino mice. British J Pharm Res. 2016;10(5):1.

39. Verma A, Jana GK, Sen S, Chakraborty R, Sachan S, Mishra A. Pharmacological evaluation of Saraca indica leaves for central nervous system depressant activity in mice. J Pharm Sci Res. 2010;2(6):338-43.

40. Campbell CG. Grass pea, Lathyrus sativus L. In: Bioversity International; 1997.

41. Muhammad N, Saeed M, Khan H. Antipyretic, analgesic and antiinflammatory activity of Viola betonicifolia whole plant. BMC Complement Altern Med. 2012;12:59.

42. Loganayaki N, Siddhuraju P, Manian S. Antioxidant, anti-inflammatory and anti-nociceptive effects of Ammannia baccifera L. (Lythracceae), a folklore medicinal plant. J Ethnopharmacol. 2012;140:230-3.

43. Khan H, Saeed M, Gilani AUH, Khan MA, Dar A, Khan I. The antinociceptive activity of Polygonatum verticillatum rhizomes in pain models. J Ethnopharmacol. 2010;127(2):521-7.

44. Alam MA, Subhan N, Awal MA, Alam MS, Sarder M, Nahar L, et al. Antinociceptive and anti-inflammatory properties of Ruellia tuberosa. Pharm Biol. 2009:47:209-14.

45. Abdala S, Dévora S, Martín-Herrera D, Pérez-Paz P. Antinociceptive and antiinflammatory activity of Sambucus palmensis link, an endemic Canary Island species. J Ethnopharmacol. 2014;155:626-32.

46. Milano J, Oliveira SM, Rossato MF, Sauzem PD, Machado P, Beck P, Zanatta $\mathrm{N}$, et al. Antinociceptive effect of novel trihalomethyl-substituted pyrazoline methyl esters in formalin and hot-plate tests in mice. Eur J Pharmacol. 2008; 581:86-96.

47. Verma PR, Joharapurkar AA, Chatpalliwar VA, Asnani A. Antinociceptive activity of alcoholic extract of Hemidesmus indicus r.Br. In mice. J Ethnopharmacol. 2005;102:298-301.

48. Binny K, Kumar SG, Dennis T. Anti-inflammatory and antipyretic properties of the rhizome of Costus speciosus (koen.) sm. J Basic Clinical Pharm. 2010; 1(3):177.

49. Rang HP, Dale MM, Ritter JM, Moore PK. Pharmacology. 6th ed. Edinburgh: Churchill Livingstone; 2007.

50. Hossain E, Mandal SC, Gupta JK. Phytochemical screening and in-vivo antipyretic activity of the methanol leaf-extract of Bombax malabaricum DC (Bombacaceae). Tropical J Pharma Res. 2011;10(1)

\section{Submit your manuscript to a SpringerOpen ${ }^{\circ}$ journal and benefit from:}

- Convenient online submission

- Rigorous peer review

- Open access: articles freely available online

- High visibility within the field

- Retaining the copyright to your article 